\title{
A PRÁTICA SOCIAL DA LEITURA E OS TEXTOS-MOTIVADORES NA REDAÇÃO DO ENEM: PRERROGATIVAS PARA O DESEMPENHO ESPERADO NA COMPETENCIA CINCO?
}

\author{
READING AS A SOCIAL PRACTICE AND THE TEXTS IN ENEM COMPOSITION: \\ PREROGATIVES FOR THE EXPECTED PERFORMANCE ON COMPETENCE FIVE?
}

\author{
Kelly Alexandra Scharf \\ Mestranda em Linguística Aplicada - PPGL/UFSC \\ kellyscharf@gmail.com
}

\begin{abstract}
RESUMO: A presente pesquisa apresenta uma análise da relação entre a prática social de leitura, os textos-motivadores e o desempenho obtido pelos participantes do ENEM na competência 5. Para tanto, foram considerados objetos desta pesquisa os relatórios pedagógicos, divulgados pelo INEP, no período compreendido entre 2000 e 2008, dos quais obtivemos os dados referentes às práticas sociais de leitura, bem como o desempenho dos participantes na competência 5. Concluindo a tríade para a análise, selecionamos os textosmotivadores constantes dos cadernos de prova para as redações do ENEM do mesmo período. Constituem-se como referencial um breve histórico sobre os estudos de letramento e a teoria dos gêneros do discurso. Por conseguinte, como observamos, a elaboração, aplicação e a avaliação das redações são feitas pelo governo. Logo, procedemos à análise do que dizem os documentos que parametrizam a Educação Básica no Brasil, a fim de relacioná-los ao referencial teórico. Por meio das teorias dos letramentos e dos gêneros do discurso, temos por objetivo verificar se há relação entre a prática social da leitura, os textos-motivadores e o desempenho na competência 5. O estudo possibilita entrever o quanto as práticas e eventos de letramento escolares distanciam-se, em certa medida, dos eventos de letramento requeridos socialmente, perpetuando as diferenças da pirâmide social.
\end{abstract}

PALAVRAS-CHAVE: Redação do ENEM. Letramento. Gêneros do discurso.

ABSTRACT: The present research focuses on analyzing the relationship between the social practice of reading, the text-motivators and the performance achieved by ENEM participants on competence 5. For this purpose, this research was based on data from the pedagogical reports published by INEP, in the period between 2000 and 2008, which provided the data concerning the social practices of reading, as well as the performance of participants on competence 5. In addition, we selected text-motivators found in notebooks of the ENEM exam in the same period. A brief history about the literacy studies and the theory of the speech genres constitute the reference work. We also observed that the preparation, the implementation and the evaluation are made by the Government. Therefore, we proceeded with the analysis of what the documents of Basic Education in Brazil establish, in order to relate them to the theoretical reference. Through the literacy theories and the speech genres, we aim to analyze whether a relation is possible between reading social practice, textsmotivators and the performance at competence 5. This study provides a glimpse of how school literacy events and literacy practices are far away, to some extent, from literacy events required socially, perpetuating the social differences.

KEYWORDS: ENEM composition. Literacy. Speech genre. 


\section{INTRODUÇÃO}

Criado em 1998, pelo Ministério da Educação (MEC), o Exame Nacional do Ensino Médio ENEM tinha como objetivo, somente, avaliar o desempenho dos estudantes concluintes do Ensino Médio, a fim de contribuir para a melhoria e qualidade da educação. Após diversas reformulações, em 2009, além de funcionar como diagnóstico da Educação Básica, passou a servir como instrumento unificado de seleção para ingresso no Ensino Superior em todas as universidades públicas brasileiras. Por sua vez, o INEP - Instituto Nacional de Estudos e Pesquisas Educacionais Anísio Teixeira, órgão vinculado ao Ministério da Educação, responsável pela elaboração, aplicação e avaliação do ENEM, divulga, desde 1998, os resultados das avaliações, as provas objetivas (e seus gabaritos), além de relatórios pedagógicos, nos quais apresentam o cruzamento entre o desempenho dos participantes e algumas variáveis socioeconômicas, cujos dados são obtidos através de questionários preenchidos pelos participantes no ato da inscrição.

Embora inicialmente voltado a universidades públicas - representadas por 120 instituições na edição 2013, ao longo dos anos, o exame tem recebido adesão de universidades privadas. Nessa edição, somaram-se mais de 500 universidades públicas e privadas, utilizando o resultado do exame como critério de seleção para o ingresso no ensino superior, seja complementando ou substituindo o vestibular. Além disso, oferecem bolsas integrais ou parciais, através de incentivos governamentais, como o Programa Universidade para Todos ProUni e o Fundo de Financiamento Estudantil - FIES (PONTUAL, 2013; ENEM, 2013). Esse exame é oferecido aos concluintes e egressos do Ensino Médio, anualmente, estruturando-se em duas partes: prova objetiva e redação. Além de ser individual e de caráter voluntário, ainda que tenha contribuído para a democratização do acesso ao ensino superior, desde a sua criação, o ENEM tem gerado polêmicas e suscitado as mais diferentes opiniões, conquistando defensores e opositores.

No que concerne à presente pesquisa, buscou-se refletir acerca de três conjuntos de dados divulgados pelo INEP: temas e textos-motivadores das redações; resultados dos "hábitos de

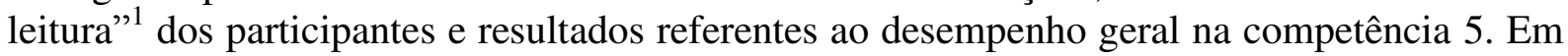
referência a essa competência, consta no Guia do Participante que ele deve: "elaborar proposta de intervenção para o problema abordado, respeitando os direitos humanos" (BRASIL, 2013, p. 8). Portanto, constituíram a base dessa análise, os dados publicados entre 2000 e 2008, uma vez que, a partir de 2009, o INEP passou a utilizar-se de microdados ${ }^{2}$ para a publicação dos relatórios pedagógicos, cuja linguagem está disponível apenas em formato $\mathrm{ASCII}^{3}$, requerendo a utilização de softwares especiais para sua interpretação. Por conseguinte, tais dados foram apreciados sob a perspectiva das teorias dos letramentos e dos gêneros do discurso.

Seguindo esse escopo, torna-se fundamental contextualizar os estudos de letramento ou New Literacy Studies (NLS) de Street (1984) e Gee 2008 [1990]), os quais têm norteado as pesquisas e o ensino de Língua Portuguesa nas últimas décadas (HEATH, 1982; STREET, 1984, 1993, 2003, 2007; GEE, 2008 [1990], 2009; BARTON, HAMILTON, IVANIČ, 2000;

\footnotetext{
${ }^{1}$ Nesse artigo serão preservadas as nomenclaturas presentes nos relatórios pedagógicos. Todavia, ancorados nos estudos do letramento, adotamos a concepção de leitura como prática social, na qual os sujeitos são sóciohistóricos e os usos que fazem das leituras estão ligados às situações de interação. (KLEIMAN, 2004).

${ }^{2}$ Disponíveis em: <http://portal.inep.gov.br/basica-levantamentos-microdados>. Acesso em: 2 out. 2013.

${ }^{3}$ ASCII ou American Standard Code for Information Interchange é usada pela maior parte da indústria de computadores para a troca de informações. Cada caracter é representado por um código de 8 bits (um byte).
} 
KATO, 1986; TFOUNI, 1988; KLEIMAN, 1995, 2002, 2004, 2007; SOARES, 1998; ROJO, 2009).

Formando o binômio que fundamentou essa análise, lança-se um olhar sobre os gêneros do discurso sob a perspectiva bakhtiniana de linguagem (BAKHTIN, 2012 [1920/1924], 2011 [1979], 2012 [1929]; SILVEIRA, ROHLING e RODRIGUES, 2012). Essa abordagem justifica-se na linha teórica adotada pelos Parâmetros Curriculares Nacionais para o Ensino Fundamental de Língua Portuguesa para o terceiro e quarto $\operatorname{ciclos}^{4}$ (de agora em diante PCNs) e pelos Parâmetros Curriculares Nacionais para o Ensino Médio (doravante PCNEM), que concebem a prática social da língua como inerente à interação verbal. Com base nesses aportes teóricos, analisamos o conjunto de dados, a fim de responder a questão de pesquisa que intitula este artigo. Afinal, há relação entre o desempenho obtido na competência 5, a prática social de leitura (letramento do participante) e os textos-motivadores? É o que procuramos responder nesse artigo, por meio da análise dos dados, a partir dos quais delineamos algumas considerações.

\section{DOS EMBASAMENTOS TEÓRICOS}

As seções a seguir constituem uma revisão dos trabalhos nas áreas de estudos dos letramentos e dos gêneros do discurso. A primeira subseção aborda um breve histórico sobre as pesquisas em letramento. Em seguida, a subseção 2.2 apresenta trabalhos publicados sobre os gêneros do discurso, bem como sua abordagem nos documentos oficiais que parametrizam o ensino de língua: os PCNs (BRASIL, 1998), PCNEM (BRASIL, 2000b) e PCNEM Plus (BRASIL, 2007e).

\subsection{Breve histórico sobre os estudos de letramento}

O termo letramento (literacy) chegou ao Brasil pelas mãos de Kato (1986), sendo também explorado por Tfouni (1988) que, pela primeira vez, propõe uma distinção entre alfabetização e letramento. Segundo esta autora, a alfabetização restringe-se à aquisição da escrita por um indivíduo ou grupo de indivíduos, enquanto o letramento aborda aspectos sócio-históricos da aquisição de um sistema escrito por uma sociedade. Dessa forma, o letramento tornou-se objeto de pesquisa tanto na Educação quanto na Linguística, motivando opiniões variadas entre especialistas. Entretanto, foi através de Soares (1998), responsável por caracterizá-lo como o ato de tornar o educando competente linguisticamente, que a expressão tornou-se amplamente conhecida.

Por outro lado, os estudos do letramento dos países anglófonos, ou New Literacy Studies (NLS), de Street (1984) e Gee (2008 [1990]) foram responsáveis por conceder um novo enfoque ao conceito de letramento, conquistando adeptos no Brasil por meio das obras de Kleiman (1995). Razão disso, explica a autora, foi a necessidade de distingui-lo de alfabetização, que se centrava nas competências individuais, enquanto o termo letramento passou a ser compreendido como "um conjunto de práticas sociais que usam a escrita, enquanto sistema simbólico e enquanto tecnologia, em contextos específicos, para objetivos específicos.” (KLEIMAN, 1995, p. 19). Para Gee (2008 [1990]), até a década de 1980, as

\footnotetext{
${ }^{4}$ A abordagem aos PCNs justifica-se em virtude de contextualizar, historicamente, a referência aos gêneros do discurso em documentos que prescrevem o currículo nacional.
} 
habilidades de ler e escrever (apenas enquanto tecnologia) foram objeto de preocupação de professores de línguas, ignorando as relações contextuais e socioculturais. $\mathrm{O}$ autor acrescenta que, quando um aluno recebia um texto, deveria depreender o único sentido correto, que viria de sua mente, desprezando conhecimento, experiência e vivência intrínsecos ao ato de interpretar. Nesse sentido, reconhecendo as múltiplas possibilidades que uma leitura pode proporcionar, conclui o autor que

[...] qualquer letramento tem a ver com leitura, e esta deve explicar-se, no mínimo, como múltiplas habilidades de 'ler' certos tipos de textos, de certos modos ou de certos níveis. Há, obviamente, muitas habilidades aqui, cada uma delas um tipo de letramento, um dentre um conjunto de letramentos. ${ }^{5}$ (GEE, 2008 [1990], p. 44, tradução nossa).

Posicionando a compreensão como inerente ao contexto, Gee (2009) afirma que os significados são sempre situados, já que repletos de intenções e valores, em tudo há ideologia, garante. Estudioso das obras de Freire (2011, p. 20), para quem "a compreensão do texto a ser alcançada por sua leitura crítica implica a percepção das relações entre o texto e o contexto", Gee (2009) sustenta que a teoria do letramento não pode ficar restrita apenas ao estudo da linguagem escrita (ler e escrever), mas deve incluir o "estudo do mundo historicamente, socialmente, institucionalmente, culturalmente e interativamente percebido e interpretado." (GEE, 2009, p. 6, tradução nossa).

Da mesma forma, Barton, Hamilton e Ivanič (2000) afirmam que é impossível conceituar letramento dissociando-o do mundo, da cultura, das práticas sociais. Esses teóricos também corroboram o pensamento bakhtiniano e apontam que Lemke ${ }^{7}$ (1995 apud BARTON, HAMILTON e IVANIČ, 2000, p. 9) destaca a importância da análise da língua através de eventos sociais de interação verbal, ao contrário da apreciação do texto fora de seu contexto. Ainda, fundamentados em Street (1993), os autores citam dois conceitos presentes na teoria do letramento, que são as práticas de letramento e os eventos de letramento. Eles explicam que aquelas estão materializadas através do que as pessoas fazem com o letramento, sem entretanto, constituírem-se apenas como

[...] mecanismos de comportamento, uma vez que também envolvem valores, atitudes, sentimentos e relações sociais (ver Street, 1993 p. $12^{8}$ ). Isso inclui a consciência das pessoas a respeito do letramento, construções do letramento e discursos de letramento, como as pessoas falam e compreendem o letramento. ${ }^{9}$ (BARTON, HAMILTON e IVANIČ, 2000, p. 7, tradução nossa).

\footnotetext{
${ }^{5}$ Texto original: "[...] whatever literacy has to do with reading, reading must be spelled out, at the very least, as multiple abilities to "read" texts of certain types in certain ways or to certain levels. There are obviously many abilities here, each of them a type of literacy, one of a set of literacies."

6 Texto original: "study of the world as historically, socially, institutionally, culturally, and interactively perceived and interpreted."

${ }^{7}$ LEMKE, J. L. Textual Politics: discourse and social dynamics. London: Taylor \& Francis, 1995.

${ }^{8}$ STREET, B. V. Cross-cultural approaches to literacy. Cambridge: Cambridge University Press, 1993.

9 Texto original: "[...] units of behaviour since they also involve values, attitudes, feelings and social relationships (see Street, 1993, p. 12). This includes people's awareness of literacy, constructions of literacy and discourses of literacy, how people talk about and make sense of literacy.” (Tradução livre).
} 
Embora estabeleçam que as práticas de letramento estão mais relacionadas aos contextos, envolvendo os modos culturais como as pessoas lidam com elas, os autores compreendem que os eventos de letramento estão, consequentemente, inseridos nas práticas, uma vez que todo evento é mediado por um texto. Em suma, para eles,

[...] esses três componentes: práticas, eventos e textos fornecem a primeira proposição de uma teoria social do letramento, qual seja: o letramento é melhor compreendido como um conjunto de práticas sociais; essas são perceptíveis nos eventos que são mediados por textos escritos. ${ }^{10}$ (BARTON, HAMILTON e IVANIČ, 2000, p. 9, tradução nossa).

No mesmo sentido, Heath (1982) também propõe que eventos de letramento são aqueles nos quais o texto medeia as interações. Além do mais, complementa que as práticas de letramento envolveriam as crenças ou valores que um determinado grupo social tem sobre leitura e escrita. Para a autora, cada comunidade possui regras de interação para os eventos de letramento e, sob um viés antropológico, argumenta que todo evento de letramento precisa ser interpretado a partir de seu contexto sociocultural, tornando compreensíveis os padrões de comportamento e usos dos quais se apropriam os usuários para o desenvolvimento da leitura e da escrita.

Todavia, para Street $(1984,1993,2003,2007)$, a leitura e a escrita não estão encerradas apenas em contextos sociais ou culturais, mas inclusive e - principalmente, nas relações de poder e autoridade. Dessa maneira, Street (1984) distingue o letramento autônomo do ideológico, explicando que este se preocupa mais com as práticas sociais. No entanto, o autor esclarece que, independente da prática adotada pelo professor, quer se preocupe da leitura e escrita como práticas sociais, quer compreenda o ensino de língua como um estágio encerrado na aquisição do código escrito, haverá ideologia presente na sala de aula, pois segundo Bakhtin (2012 [1929]), toda linguagem é constituída de ideologia.

Por conseguinte, espera-se que o aluno desenvolva a habilidade de compreender os textos em suas situações sociais de interação, em suas entrelinhas, visto que conforme Street (2003):

[...] o modelo ideológico de letramento oferece um ponto de vista culturalmente mais sensível das práticas de letramento, da forma como variam de um contexto ao outro. Esse modelo baseia-se em diferentes premissas do modelo autônomo - coloca, em vez disso, que o letramento é uma prática social, não simplesmente uma habilidade técnica e neutra; sempre está embutida em princípios epistemológicos socialmente construídos. É sobre o conhecimento: os caminhos pelos quais as pessoas dirigem a leitura e a escrita arraigam-se em conceitos de conhecimento, identidade e ser. Também está sempre imbricado em práticas sociais, como aquelas de um determinado mercado de trabalho ou de um determinado contexto educativo, e os efeitos da aprendizagem de um letramento particular, dependerão desses determinados contextos. ${ }^{11}$ (STREET, 2003, p. 77-78, tradução nossa).

\footnotetext{
${ }^{10}$ Texto original: "these three components, practices, events and texts, provide the first proposition of a social theory of literacy, that: literacy is best understood as a set of social practices; these are observable in events which are mediated by written texts. [...]."

${ }^{11}$ Texto original: "[...] the ideological model of literacy, offers a more culturally sensitive view of literacy practices as they vary from one context to another. This model starts from different premises than the
} 
Acompanhando essa concepção, Barton, Hamilton e Ivanič (2000) reiteram que cada contexto da vida social representaria demandas específicas de letramento, exigindo variados níveis de conhecimento e poder social. Outrossim, Rojo (2009) reforça essas teorias e explica que:

o termo letramento busca recobrir os usos e práticas sociais de linguagem que envolvem a escrita de uma ou de outra maneira, sejam eles valorizados ou não valorizados, locais ou globais, recobrindo contextos sociais diversos (família, trabalho, mídias, escola, etc.), numa perspectiva sociológica, antropológica e sociocultural. (ROJO, 2009, p. 98).

Quanto ao conceito de letramentos locais versus letramentos globais, Rojo (2009, p. 115) esclarece que cabe à escola estabelecer diálogos entre culturas locais e culturas valorizadas (urbanas), "não para servir à cultura global, mas para criar coligações contra-hegemônicas, para translocalizar lutas locais.”. Entretanto, Rojo (2009, p. 108) compreende que a escola, no papel de agência de letramento (termo cunhado por Kleiman [1995]), precisa ampliar as práticas de leitura e escrita para além dos "gêneros escolares (anotações, resumos, [...], questionários, dentre outros)", bem como dos "gêneros escolarizados advindos de outros contextos (literário, jornalístico, publicitário)" (ROJO, 2009, p. 108). Isso significa ampliar a participação dos alunos em várias práticas sociais, de forma que possam atuar criticamente, exercendo seu papel de forma democrática e cidadã, como postulou Freire (2011). Segundo Rojo (2009), "precisamos ainda, aprofundar um pouco mais o conceito de letramentos múltiplos ou multiletramentos e o de letramentos críticos" (ROJO, 2009, p. 108, grifos da autora), a fim de garantir o acesso e democratização das práticas e eventos de letramento dos textos que circulam na escola, expandindo-os para os eventos e práticas globais. A autora, inclusive, explica que o conceito de letramentos múltiplos ou multiletramentos é um tanto complexo e, não raro, ambíguo,

pois envolve, além da questão da multissemiose ou multimodalidade das mídias digitais que lhe deu origem, pelo menos duas facetas: a multiplicidade de práticas de letramento que circulam em diferentes esferas ${ }^{12}$ da sociedade e a multiculturalidade, isto é, o fato de que diferentes culturas locais vivem essas práticas de maneira diferente. (ROJO, 2009, p. 108-109).

Em virtude dessa multimodalidade, Kleiman (2007) reconhece que a escola não é a única agência de letramento, mas a mais importante, desempenhando papel central na formação do aluno, valorizando e estimulando práticas sociais de leitura e escrita que ampliem o repertório cultural dele, no intuito de aprimorar seu protagonismo na sociedade. Nesse sentido, assegura

autonomous model - it posits instead that literacy is a social practice, not simply a technical and neutral skill; that it is always embedded in socially constructed epistemological principles. It is about knowledge: the ways in which people address reading and writing are themselves rooted in conceptions of knowledge, identity, and being. It is also always embedded in social practices, such as those of a particular job market or a particular educational context and the effects of learning that particular literacy will be dependent on those particular contexts."

${ }^{12}$ O conceito de esferas discursivas ou domínios sociodiscursivos em Bakhtin (2011 [1979], 2012 [1929]) referese, basicamente, às áreas de circulação dos gêneros do discurso em relação às suas finalidades. Exemplificando: gêneros da esfera judicial têm, geralmente, a finalidade de realizar julgamentos; gêneros da esfera publicitária, do mesmo modo, agrupam-se pelos objetivos comerciais. 
[...] que é na escola, agência de letramento por excelência de nossa sociedade, que devem ser criados espaços para experimentar formas de participação nas práticas sociais letradas e, portanto, acredito também na pertinência de assumir o letramento, ou melhor, os múltiplos letramentos da vida social, como o objetivo estruturante do trabalho escolar em todos os ciclos. (KLEIMAN, 2007, p. 4).

A partir dessa assertiva, conclui-se a importância do letramento como possibilidade de transformação social, revelando-se basilares não apenas a formação escolar (que para muitos representa a única agência de letramento na vida), mas também o acesso às culturas dominantes, uma vez que, em virtude de sua essência ideológica, a linguagem está sempre submetida aos interesses de seus usuários. De acordo com Gnerre (2009, p. 5) "as pessoas falam para serem 'ouvidas', às vezes para serem respeitadas e também para exercer uma influência no ambiente em que realizam os atos linguísticos.". No papel de principal agência de letramento, a escola é responsável por estabelecer condições para que o aluno seja capaz de atuar em todas as práticas sociais de leitura e escrita, sobretudo as pertencentes às culturas valorizadas socialmente. Referendando a luta de classes, presente na teoria marxista, Gramsci (1982) expõe a importância da escola e do papel docente:

daí porque é possível dizer que, na escola, o nexo instrução-educação somente pode ser representado pelo trabalho vivo do professor, na medida em que o mestre é consciente dos contrastes entre o tipo de sociedade e de cultura que ele representa e o tipo de sociedade e de cultura representado pelos alunos, sendo também consciente de sua tarefa, que consiste em acelerar e em disciplinar a formação da criança conforme o tipo superior em luta com o tipo inferior. (GRAMSCI, 1982, p. 131, nossos grifos).

Essa reflexão incorpora a acepção de letramento como prática social essencialmente ideológica, validando a sugestão de Serra (2003) que defende ser responsabilidade dos governantes desenvolver práticas de promoção da leitura e investir em agências de difusão da cultura, a fim de formar leitores, tais como: escolas, bibliotecas, TV e rádio. A autora ainda considera importante o entorno cultural e o grupo ao qual pertencem os indivíduos como oportunidade de acesso aos bens culturais.

É nesse ponto que a teoria dos letramentos e dos gêneros do discurso entreolham-se como interdependentes e complementares na formação dos multiletramentos, dos letramentos críticos (ROJO, 2009) e do protagonismo defendido por Freire (2011). Conforme Kleiman (2007), é o grau de familiaridade do aluno com textos dos mais variados gêneros, de diversas esferas de circulação que o tornarão capaz de "comunicar-se em eventos que pressupõem essa prática" (KLEIMAN, 2007, p.7). O preenchimento de requerimentos, por exemplo, presente em variadas esferas de atividade social, pode cumprir diferentes objetivos, dependendo da esfera de circulação (acadêmica, escolar, religiosa). Para ela, a escola, no papel de principal agência de letramento, pode proporcionar que a leitura torne-se mais simples para o leitor frequente, uma vez que se familiariza com o léxico e semântica dos textos (KLEIMAN, 2002). Logo, as leituras consideradas difíceis seriam aquelas com as quais o leitor tem pouca afinidade/conhecimento. Desse modo, a subseção a seguir, visa encontrar a relação entre a teoria dos gêneros do discurso e o que está prescrito sobre seu ensino nos documentos oficiais. 


\subsection{A teoria dos gêneros do discurso e dos documentos oficiais}

Nos documentos que regulamentam o currículo escolar no país, a teoria de gêneros teve sua primeira aparição oficial nos Parâmetros Curriculares Nacionais para o terceiro e quarto ciclos do Ensino Fundamental, os PCNs. É este documento que embasa o ensino de Língua Portuguesa para alunos do $6^{\circ}$ ao $9^{\circ}$ anos, afirmando que:

todo texto se organiza dentro de determinado gênero em função das intenções comunicativas, como parte das condições de produção dos discursos, as quais geram usos sociais que os determinam. Os gêneros são, portanto, determinados historicamente, constituindo formas relativamente estáveis de enunciados, disponíveis na cultura. (BRASIL, 1998, 21, grifos nossos).

No destaque, referência à teoria bakhtiniana para quem "cada enunciado particular é individual, mas cada campo de utilização da língua elabora seus tipos relativamente estáveis de enunciados, os quais denominamos gêneros do discurso." (BAKHTIN, 2011 [1979], p. 262, grifos do autor). No entanto, apesar de sua teoria aparecer diluída no corpo dos PCNs, Bakhtin só é referenciado na bibliografia desse documento.

Em 2000, a fim de cumprir com a disposição legal registrada na Lei de Diretrizes e Bases da Educação Nacional n. 9.394/96 (BRASIL, 1997), o Ministério da Educação (MEC) publica os Parâmetros Curriculares Nacionais para o Ensino Médio - linguagens, códigos e suas tecnologias, parte II (PCNEM), que passaram a fundamentar o ensino de Língua Portuguesa, Língua Estrangeira Moderna, Educação Física, Arte e Informática para o Ensino Médio, seguindo a mesma linha teórica dos PCNs, no que se refere ao ensino de língua portuguesa. No entanto, ao contrário dos PCNs, esse documento traz uma única referência a Bakhtin, sem indicação da obra consultada:

nas práticas sociais, o espaço de produção de sentidos é simultâneo. Nesse, as linguagens se estruturam, normas (códigos) são partilhadas e negociadas. Como diz Bakhtin, a arena de luta daqueles que procuram conservar ou transgredir os sentidos acumulados são as trocas linguísticas, relações de força entre interlocutores. (BRASIL, 2000b, p. 6).

Tal afirmação coaduna-se com a asserção que Bakhtin (2012 [1929], p. 47, grifos no original) faz sobre signo ideológico: "[...] em todo signo ideológico confrontam-se índices de valor contraditórios. O signo se torna a arena onde se desenvolve a luta de classes. Esta plurivalência social do signo ideológico é um traço da maior importância." Nessa passagem, o autor propõe a reflexão acerca do valor ideológico do signo linguístico, atentando para suas diferenças, dependendo dos interlocutores, das posições que ocupam socialmente, bem como de suas intenções. Assim, o exemplo citado por Silveira, Rohling e Rodrigues (2012) ilustra melhor essa perspectiva:

mesmo que o signo seja igual do ponto de vista material, ele carrega nele vários sentidos, isso remete ao caráter de plurivalência dos signos. Tomemos brevemente um exemplo focal para demonstrar como os signos adquirem 
sentido nos enunciados através dos horizontes axiológicos que os balizam. A palavra terra assume sentidos diferentes se enunciada por uma pessoa se afogando, por um astronauta que vê a terra do espaço, por um grande proprietário de terra, por um meeiro etc. (SILVEIRA, ROHLING e RODRIGUES, 2012, p. 105, grifos das autoras).

Organizado por disciplinas, o documento subdivide cada uma delas em: conhecimento da disciplina e, competências e habilidades a serem desenvolvidas nas áreas. Na disciplina de Língua Portuguesa, aparece a definição de gênero do discurso: "Os gêneros discursivos cada vez mais flexíveis no mundo moderno nos dizem sobre a natureza social da língua." (BRASIL, 2000b, p. 21). Essa abordagem vai ao encontro do conceito de língua de Bakhtin (2012 [1929]), afirmando que:

na realidade, o ato de fala, ou, mais exatamente, seu produto, a enunciação, não pode de forma alguma ser considerado como individual no sentido estrito do termo; não pode ser explicado a partir das condições psicofisiológicas do sujeito falante. A enunciação é de natureza social. (BAKHTIN, 2012 [1929], p. 113, grifos do autor).

A respeito da enunciação, explicam Silveira, Rohling e Rodrigues (2012, p. 31), que o enunciado proposto pelo autor é o de unidade de interação, uma vez que "nosso discurso materializa-se em enunciados, sejam eles enunciados verbais orais, verbais escritos ou materializados em outra materialidade semiótica, como o desenho, a música etc." Portanto, admitir que toda enunciação acontece socialmente, implica contextualizá-la, assumindo os valores do signo ideológico, suas tensões e intenções. Em outro excerto dos PCNEM (BRASIL, 2000b), os autores reconhecem o processo dialógico de toda e qualquer enunciação, estabelecendo que:

toda e qualquer análise gramatical, estilística, textual deve considerar a dimensão dialógica da linguagem como ponto de partida. O contexto, os interlocutores, gêneros discursivos, recursos utilizados pelos interlocutores para afirmar o dito/escrito, os significados sociais, a função social, os valores e o ponto de vista determinam formas de dizer/escrever. (BRASIL, 2000b, p. 21, nossos grifos).

Com o lançamento dos Parâmetros Curriculares Nacionais Plus para o Ensino Médio, em 2007, que descreve como objetivo principal ser um auxiliar na organização do trabalho escolar, ajudando o professor no planejamento e condução da disciplina, observa-se uma dissonância teórica, tanto no contraste com os PCNs, quanto com os PCNEM, de 1998 e 2000, respectivamente. E, embora Bakhtin apareça referenciado, as acepções aos gêneros figuram em propostas como: "Uma aula da disciplina Língua Portuguesa, que integra a área de Linguagens e Códigos, ao tratar dos gêneros narrativos ou descritivos [...]" (BRASIL, 2007 e, p. 15, grifos nossos). A partir dessa asserção, nota-se que a concepção de gêneros vai de encontro ao que prescreviam os documentos anteriores e, sobretudo, ao conceito de 
Bakhtin, dado que, da forma como está, aproxima-se sobremaneira da Linguística Textual da década de $1980^{13}$ e suas correspondentes tipologias ${ }^{14}$.

Nesse sentido, conquanto os PCNs e os PCNEM demonstrem-se alicerçados no conceito bakhtiniano de linguagem, dentre os quais: dialogia, interação, contexto e "formas relativamente estáveis de enunciados", isto é, os gêneros do discurso, ancorando-se em diversas obras desse filósofo da linguagem, os PCNEM Plus parecem querer retomar o ensino comunicativo de língua da década de 1970. Consequentemente, por reconhecer o ensino interacional da língua como um caminho epistemologicamente alinhado às teorias do letramento e socialmente viável ao protagonismo dos alunos e, ainda, por tratar-se de documentos vigentes, para fins de análise, serão adotados os PCNs e PCNEM.

A explicação para que as teorias de Bakhtin encontrem-se estabelecidas nesses documentos, que parametrizam o ensino na área de línguas, além do fato de seus autores serem linguistas e estudiosos das obras bakhtinianas, pode ser encontrada em Rodrigues (2005):

é como problematizador e interlocutor produtivo que podemos situar o Círculo de Bakhtin $^{15}$ na linguística aplicada, pois as suas idéias têm impulsionado as discussões teóricas e os desenvolvimentos pedagógicos na área de ensino de línguas a partir de meados da década de 1980. Suas concepções vão ao encontro das discussões teóricas da área, mesmo que o foco central de atenção do Círculo não tenha sido o ensino/aprendizagem de línguas. (RODRIGUES, 2005, p. 153).

Outro conceito apontado nos PCNEM (BRASIL, 2000b), relacionado ao ensino e aprendizagem da escrita, coaduna-se ao de letramento tratado na seção anterior, o de letramento como prática social: "a situação formal da fala/escrita na sala de aula deve servir para o exercício da fala/escrita na vida social. Caso contrário, não há razão para as aulas de Língua Portuguesa" (BRASIL, 2000b, p. 22, nossos grifos). Essa afirmação posiciona a escola no centro da formação dos alunos, corroborando a assertiva de Kleiman (1995), que a vê como principal fomentadora das práticas sociais de leitura e escrita.

Além disso, esse documento ressalta a importância dos conceitos de fala e escrita como prática socialmente situada, definição de Street (1984), reverberando que "toda fala/escrita é histórica e socialmente situada, sua atualização demanda uma ética." (BRASIL, 2000b, p.22). Importa, sobretudo, frisar que a despeito de apresentarem as referências, os autores não se utilizam de citações diretas ou indiretas no corpo dos documentos. Assim, as vozes autorais caracterizam-se pelo reconhecimento das obras referenciadas.

Retomando a afirmação anterior, os PCNEM não se preocupam em definir o que constituiria a ética no ensino de línguas. Apesar de termos como ética, estética e política aparecerem também na Lei de Diretrizes e Bases da Educação n. 9.394/96 (BRASIL, 1997), tanto os

\footnotetext{
13 A Linguística Textual, dentro do campo de estudos da Linguística Aplicada, na década de 1980, possuía inclinação mais gramatical, assumindo um enfoque pragmático-discursivo na década seguinte. Nos últimos anos, porém, essa disciplina relaciona-se mais ao processamento sociocognitivo de textos orais e escritos. (Ver KOCH, 2009; RODRIGUES et al., 2012).

${ }^{14}$ Segundo Travaglia (2012, p. 364), as tipologias podem ser divididas em oito categorias: "a) texto descritivo, dissertativo, injuntivo, narrativo; b) texto argumentativo 'stricto sensu' e argumentativo não 'stricto sensu'; c) texto preditivo e não preditivo; d) texto do mundo comentado e do mundo narrado; e) texto lírico, épico/ narrativo e dramático; f) texto humorístico e não humorístico; g) texto literário e não literário; h) texto ficcional e factual."

${ }^{15}$ Círculo de Bakhtin era formado por intelectuais russos, dentre eles Bakhtin, Voloshínov e Medviédev. (Para ampliação, ver RODRIGUES, 2005).
} 
PCNEM quanto a LDB deixam de esclarecer o que seria um ensino ético, talvez por pressupôlo como integrante do senso comum. Desse modo, em razão de os documentos fundamentarem o ensino e a aprendizagem de línguas nos autores ora relacionados, sobretudo na teoria bakhtiniana, acredita-se que seja pertinente consultar sua definição sobre ética, sem a intenção de esgotar o assunto. Portanto, submete-se a reflexão de Bakhtin (2012 [1920/1924]) sobre os fundamentos do ato ético, em que refuta a ética materialista, por compreendê-lo como um ato intrinsecamente moral. Em suas palavras, explica que

\footnotetext{
é necessário, ainda, alguma coisa que tenha origem em mim, precisamente a orientação do dever moral de minha consciência em relação à proposição em si teoricamente válida. É justamente essa orientação moral da consciência que é ignorada pela ética material, a qual passa mesmo por cima do problema que aqui se esconde, sem vê-lo. (BAKHTIN, 2012 [1920/1924], p. 74 , nossos grifos).
}

Com base na ética moral do autor e nas teorias já relacionadas vislumbra-se um ensino de língua que contemple a diversidade, que se fundamente em práticas sociais e que leve em consideração seus sujeitos - apesar de suas consciências -, respeitando-os e oferecendo oportunidades para que circulem em variadas esferas de atividades ou de circulação de discursos. Rojo (2009) formula hipóteses que podem nortear o trabalho do professor, nas seguintes questões: "Como organizar, na escola, a abordagem de tal multiplicidade de práticas? Que eventos de letramento e que textos selecionar? De que esferas? De que mídias? De quais culturas?" e assegura que os conceitos bakhtinianos conduzirão às respostas, desde que o professor tenha como base o trabalho com os gêneros dos discursos, de variadas esferas de circulação sociais, em diferentes posições, "como produtores ou receptores/consumidores de discursos, em gêneros variados, mídias diversas e em culturas também diferentes." (ROJO, 2009, p. 109). Sob esses pressupostos teóricos, bem como os de ensino de Língua Portuguesa embasaremos as análises a seguir.

\section{METODOLOGIA E ANÁLISE DOS DADOS}

Desde a sua implantação, em 1998, o INEP é responsável pelo processo que avalia os concluintes do Ensino Médio, seja na esfera regular de ensino, na Educação de Jovens e Adultos (EJA) ou nos ensinos técnico e/ou profissionalizante. Em 2010, o ENEM passou a ser aplicado nas unidades prisionais e instituições socioeducativas, mediante termo de compromisso firmado entre essas instituições e o INEP. Nesse processo, as inscrições, acesso aos resultados e divulgação das informações do exame aos inscritos são realizadas pelos responsáveis pedagógicos, via internet.

Em virtude das mudanças, mencionadas na introdução deste artigo, as análises realizadas nessa pesquisa estão restritas ao período de 2000 a 2008 por duas razões. A primeira refere-se ao lançamento dos PCNEM em 2000. A segunda, por questões de ordem técnica, uma vez que, a partir de 2008 o INEP deixou de disponibilizar os dados abertos, como vinha fazendo com os relatórios pedagógicos até então. Desde 2009, todas as informações e dados relacionados aos resultados do ENEM, como os questionários respondidos pelos participantes (questionário socioeconômico) e o desempenho nas avaliações (prova objetiva e redação) passaram a ser divulgados através de microdados, em linguagem de programação ASCII, usada pela maior parte da indústria de computadores para a troca de informações. Entretanto,

Work. Pap. Linguíst., 15(1): 14-42, Florianópolis, jan/abr, 2014 
além do conhecimento necessário para a conversão desse tipo de dado, essa linguagem requer a utilização de softwares especiais para sua interpretação. Dessa forma, as análises compreendem o período de 2000 a 2008, baseando-se em três conjuntos de dados extraídos dos relatórios pedagógicos, divulgados pelo INEP, sob os títulos:

a) Resultados dos hábitos de leitura dos participantes;

b) Temas e textos-motivadores das redações;

c) Desempenho geral na competência 5.

Tais escolhas originaram-se no desempenho obtido pelos participantes na competência 5 e na asserção feita pelo INEP, no relatório pedagógico de 2004 (BRASIL, 2004b), no qual relata como sendo uma prerrogativa para o desempenho esperado do participante, a quantidade de leituras feitas por ele. Nesse sentido, visualiza-se, na figura a seguir (figura 1), composta em sua base, por um lado, pela leitura (admitida nos estudos de letramento como prática social, conhecimentos já adquiridos) e, por outro, as práticas de leitura dos textos-motivadores, que também alicerçam as produções textuais. No topo, a escrita, prática social altamente valorizada e, nesse caso, representada pelo desempenho dos participantes na competência 5 . Assim, nossa análise tem por objetivo verificar se há relação entre: o desempenho obtido na competência 5, a prática social de leitura (letramento do participante) e os textos-motivadores. Para tanto, cada um desses itens constituirá uma seção, com a apresentação dos dados coletados e respectivas análises.

Figura 1: Trilogia da Redação do NEM

Prática Social da Escrita

(desempenho esperado na produção da redação)

(C)

Prática Social da Leitura (letramento do participante)

(A)

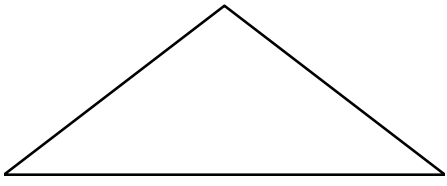

Prática Social da Leitura (textos-motivadores)

(B)

Fonte: Elaborado pela autora

\subsection{O que dizem os "Habitos de Leitura"}

A partir dos temas e textos-motivadores buscou-se os "hábitos de leitura" (coletados nos questionários socioeconômicos), nos relatórios pedagógicos divulgados pelo MEC/INEP/ENEM de 2000 a 2008 (BRASIL, 2001b; 2002b; 2007b; 2007c; 2007d; 2008b; 2008c; 2009), exceto em 2001 e 2002, por não apresentarem tais dados. Ressalte-se, ainda, 
que como em toda pesquisa interpretativista, consideram-se os diferentes horizontes axiológicos dos participantes (CELANI, 2005).

O título da tabela 1 refere-se à nomenclatura utilizada nos relatórios pedagógicos, através de gráficos sob os títulos: "Distribuição dos participantes segundo os hábitos de leitura". Esses gráficos apresentam a relação entre o tipo de leitura dos participantes, classificadas em: "romances, livros de ficção; revistas de divulgação científica (Ciência Hoje, Galileu, etc.); revistas de humor/quadrinhos; revistas de informação geral (Veja, Isto é, Época, etc.); Jornais." (BRASIL, 2001b; 2002b; 2007b; 2007c; 2007d; 2008b; 2008c; 2009) e a frequência de leitura. Contudo, apesar de os gráficos relacionarem as mesmas opções de leitura em todas as edições, em 2000, o eixo que se refere à frequência de leitura, mostra somente duas respostas "lê com frequência; lê às vezes" (BRASIL, 2001b, p. 139). Em 2003, o participante passa a contar com a opção de não-leitor e encontra-se no gráfico: "frequentemente; às vezes; não; sem resposta ou inválido" (BRASIL, 2007b, p. 62). Porém, a partir de 2004 os gráficos seguem o padrão: "frequentemente; às vezes; não" (BRASIL, 2007c, p. 55; 2007d, p. 66; 2008 b, p. 58; 2008c, p. 67; 2009, p. 85). A fim de uniformizar a apresentação dos dados na tabela, serão utilizadas as letras $F$, para frequentemente, $A$, para às vezes e $N$ para não (que identifica os participantes que se declararam não-leitores). Por aparecer apenas na edição de 2003, não foram incluídos na análise os que não responderam ou invalidaram as respostas. Assim, têm-se os seguintes dados:

Tabela1: Distribuição dos "hábitos de leitura" (\%)

\begin{tabular}{|c|c|c|c|c|c|}
\hline CANO & $\begin{array}{l}\text { ROMANCE/ } \\
\text { FICÇÃO }\end{array}$ & $\begin{array}{c}\text { REVISTA DE } \\
\text { DIVULGAÇÃOO } \\
\text { CIENTÍFICA }\end{array}$ & $\begin{array}{l}\text { REVISTA } \\
\text { DE HUMOR }\end{array}$ & $\begin{array}{c}\text { REVISTA DE } \\
\text { INFORMAÇÃO } \\
\text { GERAL }\end{array}$ & JORNAIS \\
\hline 2000* & $\begin{array}{c}A \\
53,53 \% \\
F \\
22,72 \%\end{array}$ & $\begin{array}{c}A \\
54,49 \% \\
F \\
13,93 \%\end{array}$ & $\begin{array}{c}A \\
57,41 \% \\
F \\
11,69 \%\end{array}$ & $\begin{array}{c}\text { A } \\
51,5 \% \\
\text { F } \\
\mathbf{4 5 , 2 5 \%}\end{array}$ & $\begin{array}{c}\text { A } \\
59,46 \% \\
F \\
35,97 \%\end{array}$ \\
\hline 2003 & $\begin{array}{c}A \\
57,7 \% \\
F \\
21,3 \% \\
N \\
19,9 \%\end{array}$ & $\begin{array}{c}A \\
48,1 \% \\
F \\
6,9 \% \\
\text { N } \\
43,7 \%\end{array}$ & $\begin{array}{c}A \\
60,3 \% \\
F \\
9,7 \% \\
N \\
28,8 \%\end{array}$ & $\begin{array}{c}\text { A } \\
68,6 \% \\
F \\
18,7 \% \\
N \\
9,4 \%\end{array}$ & $\begin{array}{c}\text { A } \\
67,5 \% \\
\text { F } \\
24 \% \\
N \\
7,5 \%\end{array}$ \\
\hline 2004 & $\begin{array}{c}\text { A } \\
57,5 \% \\
\text { F } \\
22,8 \%\end{array}$ & $\begin{array}{c}A \\
48,4 \% \\
F \\
6,8 \%\end{array}$ & $\begin{array}{c}A \\
60,6 \% \\
F \\
10,4 \%\end{array}$ & $\begin{array}{c}\text { A } \\
\mathbf{7 1} \% \\
\text { F } \\
18,3 \%\end{array}$ & $\begin{array}{c}A \\
68,8 \% \\
F \\
21,9 \%\end{array}$ \\
\hline
\end{tabular}




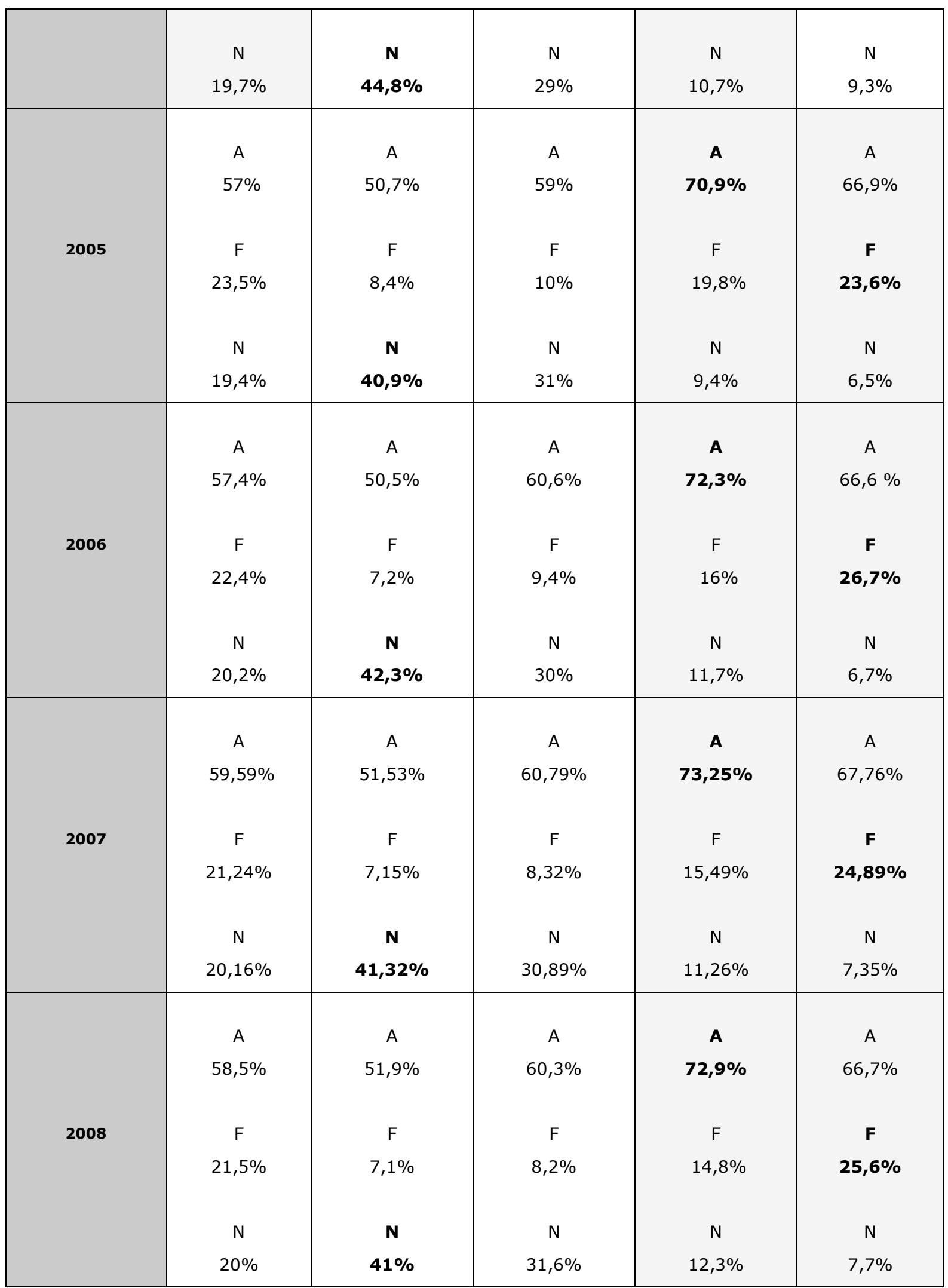

Fonte: Elaborado pela autora.

* O relatório pedagógico desse ano só apresenta duas respostas: lê frequentemente (F) e lê às vezes (A). 
Quanto aos destaques realizados na tabela acima (sombreamento e negrito), referem-se aos itens declarados com maior frequência de leitura (às vezes, frequentemente e não). Em todos os anos, com exceção de 2004, as respostas para leio "às vezes" estão acima de cinquenta por cento em todas as categorias, o que mostra que existe frequência de leitura, ainda que eventual. Outro dado relevante é o percentual - sempre acima de quarenta por cento -, de participantes que se declararam não-leitores de revistas de divulgação científica. Desse modo, prossegue-se à análise dos maiores percentuais em frequência de leitura.

Em 2000, o maior índice de leitura aparece em jornais, com 59,46\%, tendo os participantes declarado serem leitores eventuais, ou seja, que leem "às vezes". Nesse mesmo ano, a segunda maior frequência está em revistas de informação geral e 45,25\% dos participantes declararam ler "frequentemente". Os resultados de 2003 mostram que 68,6\% dos participantes assumiram a leitura "às vezes" de revistas de informação geral. Em segundo lugar está a leitura de jornais e $24 \%$ declararam ler frequentemente. Na edição de 2004, a maior frequência de leitura "às vezes" apontou para as revistas de informação geral, com $71 \%$, seguida de romance, cuja leitura aparece "frequentemente", com 22,8\%. No entanto, essa categoria não extrapola a leitura frequente de $23,5 \%$, maior índice em todas as edições, nessa opção, que ocorreu em 2005. Nesse ano, porém, o maior percentual de leitura foi de 72,3\%, "às vezes", de revistas de informação geral. Já a leitura frequente aparece com 26,7\% (maior índice), na categoria jornais. Os dados de 2007 mantêm o ranking do ano anterior, com $73,25 \%$ declarando-se leitores "às vezes" de revistas de informação geral e 24,89\% leitores frequentes de jornais. Em 2008, os maiores índices continuam concentrando-se na leitura de jornais com 25,6\% dos participantes afirmando serem leitores frequentes e 72,9\% alegaram ler "às vezes" revistas de informação geral.

Portanto, os destaques feitos na tabela evidenciam a concentração das leituras nas categorias de revistas de informação geral e de jornais, com exceção de 2004, cuja frequência maior foi a de leituras de romance/ficção. Contudo, apesar de haver uma certa restrição pelo INEP aos exemplos de revistas de divulgação científica e de informação geral (conforme indicados nos questionários entregues aos participantes), consequentemente, pode-se admitir que tenham influenciado as respostas, já que o leitor - dependendo de seu letramento -, poderia compreender os exemplos fornecidos pelo INEP, em cada categoria, como a leitura específica e restrita destes.

Outrossim, independente da compreensão dos participantes em relação às questões elaboradas para obtenção dos dados, estes revelam que não há interesse pela literatura e, mais, que as práticas de leitura concentram-se nos jornais e em revistas de informação geral como Veja, Isto é e Exame. Considera-se tal fato relevante, uma vez que os textos-motivadores das redações são, em sua maioria, oriundos de jornais e revistas, o que facilitaria a leitura em razão do letramento e, por conseguinte, melhoraria o desempenho na produção da redação. Outro dado que poderia indicar uma escolha do que seria a resposta correta, como visto em Gee (2008 [1990]), é a baixa frequência de leitura de revistas de humor/quadrinhos, que costumam ser frequentes em certas faixas etárias e classes sociais, e não aparecem em maior percentual em nenhuma edição.

Baseando-se no conceito de Gee (2008 [1990]), de que qualquer letramento tem a ver com leitura, esses dados revelam o hiato que existe entre o letramento escolar e a prática social. Nota-se a carência dos multiletramentos ou letramentos múltiplos, conforme Rojo (2009), de diferentes esferas de circulação, o que sinaliza para uma prática escolar que não tem formado leitores que vão além dos gêneros escolares ou escolarizados (KLEIMAN, 1995) e que também não tem atentado para os letramentos locais e globais (ROJO, 2009). Dessa maneira, assentir que o texto medeia as interações (HEATH, 1982; BARTON, HAMILTON E 
IVANIČ, 2000), e mais, que as práticas sociais de leitura e escrita permeiam as relações de poder (STREET, 1984, 1993, 2003, 2007), significa considerar, em certa medida, que alguns participantes concluintes do Ensino Médio não estão exercendo seu protagonismo (FREIRE, 2011) e estão distantes do que seria o letramento ideológico proposto por Street (1993).

O que esses dados mostram é uma certa padronização no conceito de leitura que, oferecendo questionários com opções para assinalar, impede que os participantes declarem a leitura que de fato realizam, quais sejam: as leituras de placas, de instruções num manual impresso ou tutorial de site, de notícias em sites ou outros dispositivos móveis (celulares, computadores portáteis), o que, sob o ponto de vista metodológico, pode-se compreender em virtude do espaço-tempo da pesquisa. A concepção que o instituto organizador transmite é a de um país que concebe como leitores apenas aqueles que sejam consumidores da relação preconizada por ele. Tal padrão revela duas percepções equivocadas, conforme Britto (2012):

uma é a visão catastrófico-denuncista de que o Brasil seria um país de nãoleitores e, portanto, com uma população pobre cultural e intelectualmente; a segunda, que acompanha a primeira como uma espécie de desiderato, é a ideia salvacionista de leitura, compreendida como um bem em si, civilizador e edificante. (BRITTO, 2012, p. 36).

A tese desse autor confirma-se na asserção presente no relatório pedagógico de 2004: "Quanto maior o índice de hábitos de leitura, maior a (sic) desempenho no Enem. A estrutura da prova baseada em situações-problema e temas da atualidade mostra a importância da leitura para o sucesso nesse tipo de prova." (BRASIL, 2004b p. 34). Além disso, o fato de o instituto declarar que a base das provas constitui-se de temas da atualidade, indica que os participantes leitores de jornais e revistas teriam melhor desempenho na produção da redação.

É por compreender a leitura como prática social que se tornam inadequadas as acepções de "hábitos de leitura", bem como na eleição de algumas leituras em detrimento de outras. Da mesma forma, Britto (2012) explica que toda leitura implica um valor, uma atitude e, assim, designá-la como um hábito, apenas, seria reduzir seu valor. Acrescenta ainda que, ao contrário do que se difunde, não é a leitura que conduz ao conhecimento, mas este é quem promove a leitura. Para ele, a leitura voluntária não é mais legítima do que a leitura por obrigação e adverte que cabe à escola o desafio de respeitar o "gosto conhecido" (BRITTO, 2012, p. 50) e promover a "leitura do mundo", preconizada em Freire (2011, p. 19). Alinhando-se aos estudos de letramento, Britto (2012, p. 50) afirma que é na escola que o agente formador terá condições de propor novas leituras e novas reflexões, "sem perder a dimensão política da formação do leitor”, conceito integrante do letramento ideológico.

\subsection{Os temas e textos motivadores}

Em todas as edições, os participantes realizam as provas em dois dias: o primeiro reservado às provas objetivas; o segundo, à redação. Nos cadernos de provas entregues a eles constam o que o instituto denomina de textos-motivadores, selecionados por seus técnicos, a fim de colaborar na produção da redação, sempre baseada em um tema, diferente todos os anos.

Os quadros a seguir apresentam os temas das redações e seus textos-motivadores, de 2000 a 2008, os quais se procurou classificar quanto ao gênero do discurso, quando possível. Entretanto, algumas vezes, em virtude da desvinculação das condições de produção ou por

Work. Pap. Linguíst., 15(1): 14-42, Florianópolis, jan/abr, 2014 
conter supressões, tornou-se inviável identificar o gênero do fragmento. Importante ressaltar que todos os textos-motivadores (assim denominados pelo INEP como textos-base para a produção da redação) relacionam-se aos temas das redações. Tais quadros foram elaboradas com base nos dados dos cadernos de prova, disponíveis no site do INEP (BRASIL, 2000a; 2001a; 2002a; 2003; 2004a; 2005; 2006; 2007a; 2008a). Estão indicadas entre colchetes as respectivas fontes, conforme apresentadas nos cadernos de provas, a fim de especificar o suporte de origem. Da mesma forma, quando houver indicação de site nos cadernos de provas, serão utilizadas as expressões jornal eletrônico ou revista eletrônica, para distinguir os textos de fontes impressas das fontes eletrônicas.

Quadro 1: Temas e textos-motivadores de 2000 a 2002

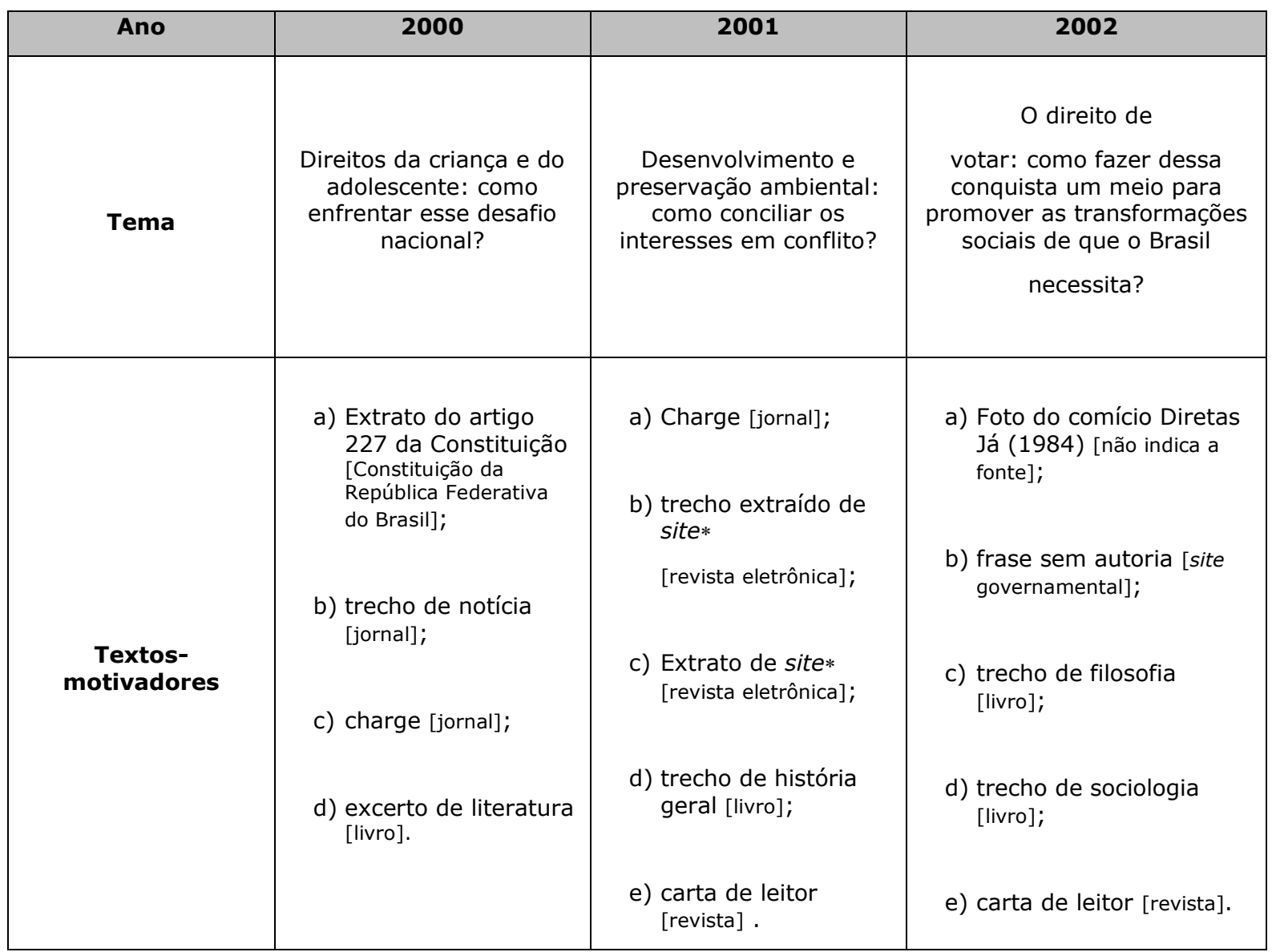

Fonte: Elaborado pela autora.

* Por estar desvinculado de suas condições de produção e por conter várias supressões, torna-se inviável identificar o gênero do fragmento.

Quadro 2: Temas e textos-motivadores de 2003 a 2005

\begin{tabular}{|c|c|c|c|}
\hline Ano & $\mathbf{2 0 0 3}$ & $\mathbf{2 0 0 4}$ & $\mathbf{2 0 0 5}$ \\
\hline Tema & $\begin{array}{c}\text { A violência na sociedade } \\
\text { brasileira: como mudar } \\
\text { as regras desse jogo? }\end{array}$ & $\begin{array}{c}\text { Como garantir a liberdade de } \\
\text { informação e evitar abusos nos } \\
\text { meios de comunicação? }\end{array}$ & $\begin{array}{c}\text { O trabalho infantil na } \\
\text { realidade brasileira. }\end{array}$ \\
\hline
\end{tabular}




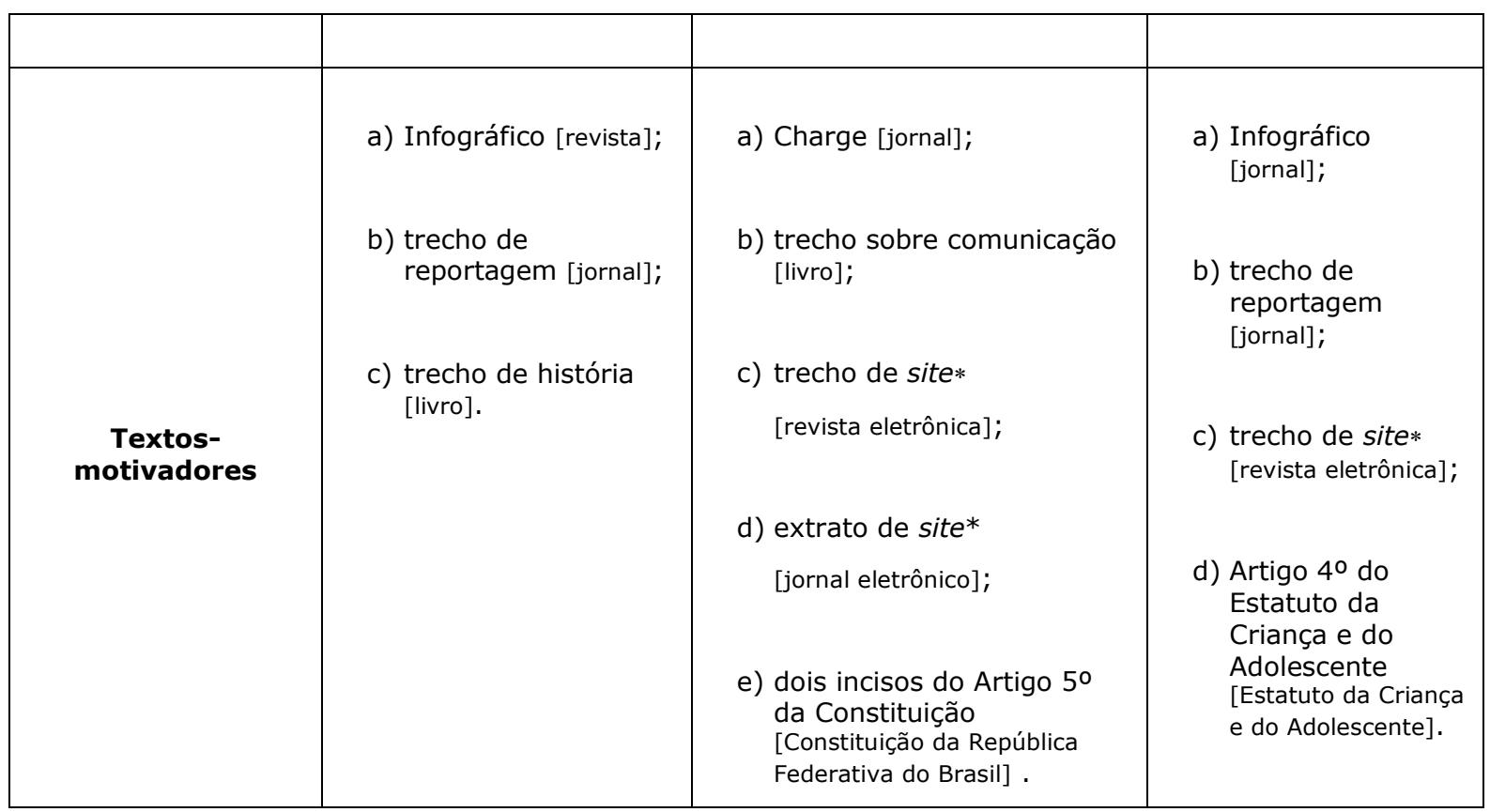

Fonte: Elaborado pela autora.

* Por estar desvinculado de suas condições de produção e por conter várias supressões, torna-se inviável identificar o gênero do fragmento.

Quadro 3: Temas e textos-motivadores de 2006 a 2008

\begin{tabular}{|c|c|c|c|}
\hline Ano & 2006 & 2007 & 2008 \\
\hline Tema & $\begin{array}{c}\text { O poder de } \\
\text { transformação da leitura. }\end{array}$ & $\begin{array}{l}\text { O desafio de se conviver } \\
\text { com a diferença. }\end{array}$ & Sem tema ${ }^{16}$ \\
\hline $\begin{array}{l}\text { Textos- } \\
\text { motivadores }\end{array}$ & $\begin{array}{l}\text { a) Trecho de artigo de } \\
\text { opinião [revista } \\
\text { eletrônica]; } \\
\text { b) trecho de relato } \\
\text { pessoal, [revista]; } \\
\text { c) extrato de artigo de } \\
\text { opinião [revista } \\
\text { eletrônica]. }\end{array}$ & $\begin{array}{l}\text { a) Duas letras de } \\
\text { música [não indica a } \\
\text { fonte]; } \\
\text { b) trecho da } \\
\text { Declaração } \\
\text { Universal sobre a } \\
\text { Diversidade Cultural } \\
\text { [UNESCO]. }\end{array}$ & $\begin{array}{l}\text { a) Trecho de reportagem } \\
\text { [jornal]. }\end{array}$ \\
\hline
\end{tabular}

Fonte: Elaborado pela autora.

\footnotetext{
${ }^{16}$ Além desse caderno de prova não apresentar tema, traz somente um texto-motivador, sem título. Apenas nessa edição, também, os participantes receberam três opções de proposta de solução para sustentar sua tese: "1.suspender completa e imediatamente o desmatamento na Amazônia, que permaneceria proibido até que fossem identificadas áreas onde se poderia explorar, de maneira sustentável, madeira de florestas nativas; 2.efetuar pagamentos a proprietários de terras para que deixem de desmatar a floresta, utilizando-se recursos financeiros internacionais; 3.aumentar a fiscalização e aplicar pesadas multas àqueles que promoverem desmatamentos não-autorizados.” (BRASIL, 2008a, p. 1).
} 
Em relação aos textos-motivadores, nota-se a preferência dos elaboradores da prova pela seleção de textos de gêneros que circulam em jornais e revistas, sendo que dos 32 textosmotivadores apresentados no período, 19 foram extraídos de jornais ou revistas (carta de leitor, notícia, reportagem, infográfico e artigo de opinião); 5 são excertos de livros (filosofia, sociologia, comunicação, história geral e literatura); 4 referem-se a publicações legais (artigo legal, inciso e declaração); além de 1 foto, 1 frase e 2 letras de música.

É oportuno destacar a ausência de elementos que possam preencher as lacunas que ficam quanto às condições de produção dos textos. Tanto que foi impossível identificar alguns excertos quanto ao gênero. Desse modo, os pressupostos teóricos encontrados nos PCNs (BRASIL, 1998) e PCNEM (BRASIL, 2000b), para os quais a língua é fruto da interação social e deve estar contextualizada (SILVEIRA, ROHLING E RODRIGUES, 2012), não aparecem nas orientações para as produções das redações do ENEM. Trazem trechos ou excertos apresentados aos participantes nos cadernos de provas, que prejudicam e confundem a compreensão, podendo valorar o texto de forma equivocada, em virtude da ausência de informações sobre as condições de produção desses textos. Percebe-se, neste sentido, que o participante deve, a partir de um quebra-cabeça de leituras, somadas ao seu letramento, compor um texto que não exceda trinta linhas.

No entanto, apesar dos recortes apresentados como subsídios à escrita, os participantes dessas edições do ENEM declararam-se leitores frequentes ou eventuais de jornais ou revistas (conforme Tabela 1), gêneros que compõem 59,4\% dos textos-motivadores do período, o que significa que os participantes possuem a leitura de jornais e revistas como prática social. $\mathrm{O}$ fato de conhecerem os gêneros através de suas práticas de leitura, contudo, não garante a produção da redação esperada, pois conforme Geraldi (2013 [1991]), toda produção textual deve abarcar que:
a) se tenha o que dizer;
b) se tenha uma razão para dizer o que se tem a dizer;
c) se tenha para quem dizer o que se tem a dizer;
d) o locutor se constitua como tal, enquanto sujeito que diz o que diz para quem diz [...];
e) se escolham as estratégias para realizar (a), (b), (c) e (d). (GERALDI, 2013 [1991], p. 137).

Ademais, não se sabe o quanto o participante esteve envolvido, na Educação Básica, com a prática da produção textual, com uma situação interlocutiva tão distinta, nesse caso, da redação do ENEM, em que terá como interlocutores previstos pelo menos, dois avaliadores, os quais objetivam analisar as redações, respeitando os critérios de cada competência.

Para que o participante esteja apto a atender aos pressupostos discursivos citados em Geraldi (2013 [1991]), é necessário mais que extratos, trechos ou excertos de textos, tornando-se fundamental que tenha o que dizer e que saiba como fazê-lo, a fim de elaborar uma proposta de intervenção que exceda os textos-motivadores, dada a sua indispensável originalidade. Além do letramento adquirido por meio de práticas sociais escolares e não-escolares, é necessário que o participante traga em sua bagagem de letramento práticas sociais relacionadas ao tema solicitado pelo ENEM. E, ainda que seja leitor frequente ou eventual de 
jornais ou revistas, é provável que jamais tenha se interessado pela leitura do assunto que embasa a proposta de intervenção a ser elaborada. Da mesma forma, retomando a trilogia da redação do ENEM (representada pela fig. 1), para que alcance o topo da pirâmide, isto é, realize uma redação que esteja dentro do mínimo esperado pelo ENEM, o participante deve ter, em sua bagagem, letramento suficiente (base $A$, fig. 1) para que os utilize na escolha das estratégias que nortearão sua produção (vértice $C$, fig. 1).

Quanto à familiaridade dos participantes com os gêneros do discurso observa-se que, em 2004 (ano cujo desempenho na competência 5 foi o mais baixo do período), eles receberam, de um total de cinco textos-motivadores, dois artigos de lei, gênero geralmente pouco desenvolvido no campo escolar. Desse modo, a inclusão desses gêneros na esfera escoar é fundamental para a construção do letramento crítico dos alunos. Sobre esse ponto, explica Bakhtin (2011 [1979], p .284): "muitas pessoas que dominam magnificamente uma língua sentem amiúde total impotência em alguns campos da comunicação precisamente porque não dominam na prática as formas de gênero de dadas esferas". Nesse ponto, apesar de referenciado nos PCNs (BRASIL, 1998) e PCNEM (BRASIL, 2000b), para os quais toda enunciação é de natureza social (BAKHTIN, 2012 [1929]), a prática da linguagem como interação social talvez não esteja presente em todos os espaços escolares, ainda.

Compreende-se a necessidade de recortes, em virtude do espaço nas redações do ENEM. Contudo, reconhecer a importância da interação no processo dialógico implica situar o texto em seu contexto, caracterizando-o como gênero do discurso. Outrossim, acredita-se que os artigos de lei não pertençam ao horizonte de prática social dos participantes, como visto na teoria dos letramentos. Entretanto, é um gênero do discurso frequente na vida social, cabendo à escola esse letramento global (ROJO, 2009).

Isso não significa que o letramento substitua a necessidade de orientação contextual do texto, porque é isto que o insere num determinado gênero do discurso, ensino preconizado nos documentos oficiais. Reitera-se, assim, que "toda fala/escrita é histórica e socialmente situada" (BRASIL, 2000b, p. 22) e, feito o recorte, perde-se a história e sua valoração social. No entanto, é preciso considerar outro ponto: o dos recortes para o ensino de língua. A metodologia do ensino de língua portuguesa, do mesmo modo, utiliza-se, frequentemente, de partes dos enunciados de diferentes gêneros para seus objetivos de ensino. Logo, a aula, o livro didático, bem como, a prova do Enem, são constituídos de gêneros intercalados ${ }^{17}$, o que, de outro modo, inviabilizaria o ensino, uma vez que o professor de língua portuguesa não utiliza - estritamente - obras integrais em suas aulas. Nesse sentido, é preciso considerar a redação do ENEM como um gênero constituído em sua historicidade.

\subsection{O desempenho geral da competência 5}

Ao realizar sua inscrição, o participante tem acesso ao Guia do Participante, elaborado pelo INEP (BRASIL, 2013), que apresenta a matriz de referência para a redação, classificando-a em cinco competências:

\footnotetext{
${ }^{17}$ Segundo Silveira, Rohling e Rodrigues (2012, p. 56), a intercalação de gêneros "ocorre quando um enunciado de um gênero A insere/intercala um enunciado (ou um trecho de enunciado que representa o enunciado inserido como um todo) de um gênero B". A aula, por exemplo, apresenta outros gêneros intercalados, tais como: avisos escolares, poemas, livro didático, notícias.
} 
[...] Competência 1 - Demonstrar domínio da modalidade escrita formal da Língua Portuguesa; Competência 2 - Compreender a proposta de redação e aplicar conceitos das várias áreas de conhecimento para desenvolver o tema, dentro dos limites estruturais do texto dissertativo-argumentativo em prosa; Competência 3 - Selecionar, relacionar, organizar e interpretar informações, fatos, opiniões e argumentos em defesa de um ponto de vista; Competência 4 - Demonstrar conhecimento dos mecanismos linguísticos necessários para a construção da argumentação; Competência 5 - Elaborar proposta de intervenção para o problema abordado, respeitando os direitos humanos. (BRASIL, 2013, p. 8, grifos nossos).

Em virtude da proposta de intervenção, que deve ser elaborada pelo participante, optou-se por avaliar os resultados apresentados pelo INEP na competência 5, por considerarmos relacionada tanto aos textos-motivadores quanto às práticas de leitura declaradas pelos participantes e apresentadas em seção anterior. Contudo, considera-se que o desempenho do participante não esteja estritamente vinculado a essas duas premissas, uma vez que possui espaço (no máximo trinta linhas) e tempo limitados para elaborar sua proposta de intervenção. Essa proposta de intervenção, sempre presente nas redações, requer do participante um bom repertório de práticas de leitura e escrita, uma vez que precisa expor sua tese, relacionando-a à vida social de forma coerente. A tabela a seguir mostra o desempenho dos candidatos na competência 5, bem como o desempenho geral, que se constitui da média geral de todas as competências, por participante.

Tabela 2: Desempenho Geral e Desempenho na Competência 5

\begin{tabular}{|l|c|c|c|c|c|c|c|c|c|}
\hline & $\mathbf{2 0 0 0}$ & $\mathbf{2 0 0 1}$ & $\mathbf{2 0 0 2}$ & $\mathbf{2 0 0 3}$ & $\mathbf{2 0 0 4}$ & $\mathbf{2 0 0 5}$ & $\mathbf{2 0 0 6}$ & $\mathbf{2 0 0 7}$ & $\mathbf{2 0 0 8}$ \\
\hline D.G $^{18}$ & 60,87 & 52,58 & 54,31 & 55,36 & 48,95 & 56 & 52,08 & 55,99 & 59,35 \\
\hline $\mathbf{D . 5}^{19}$ & 57,51 & 46,75 & 51,78 & 51,87 & 42,93 & 47,3 & 44,31 & 48,4 & 56,12 \\
\hline
\end{tabular}

Fonte: Elaborado pela autora.

Compreendendo que o desempenho na competência 5 avalia a defesa de um ponto de vista pelo participante, a partir da análise da tabela, observa-se a queda, em todos os anos, do índice nesse item. Ou seja, os participantes obtêm melhor desempenho geral do que defendendo suas teses ou propostas de elaboração para o problema (tema da redação).

Esses dados contrariam a afirmação feita no Relatório Final de 2003, no qual o MEC/Inep declara: "quanto maior o índice de hábitos de leitura, maior a ( sic) desempenho no Enem. A estrutura da prova baseada em situações-problema e temas da atualidade mostra a importância da leitura para o sucesso nesse tipo de prova" (BRASIL, 2004b p. 34). Considerando as práticas de leitura declaradas pelos participantes e, sabendo que essas se compõem dos gêneros que são oferecidos a eles como textos-motivadores, o desempenho seria melhor se a quantidade de leituras fosse garantia para o sucesso na escrita. Entretanto, a escrita é também uma prática social (KLEIMAN, 1995) e, como tal, precisa ser apresentada aos alunos desde o início da vida escolar, constituindo-se de variados gêneros do discurso. Embora a produção textual do ENEM esteja vinculada a uma tipologia que, conforme visto na subseção 2.2, não

\footnotetext{
${ }^{18}$ D.G.: Desempenho geral.

${ }^{19}$ D. 5: Desempenho na competência 5.
} 
demanda o conhecimento de vários gêneros, cabe à escola investir no letramento do aluno como forma de cidadania, não apenas tendo o ENEM como foco.

Dessa maneira, os pressupostos teóricos sobre os estudos de letramento, como os de Gee (2008 [1190]), apontam para as várias formas de ler, assim como múltiplas leituras, constituindo-se cada uma de um tipo de letramento. Compreendendo-se a leitura e a escrita como práticas sociais interligadas seria correto afirmar que, quanto maior o número de livros, revistas e jornais lidos pelo participante, assim como sua inserção social em eventos de leitura e escrita que requeiram diversas habilidades, melhor seria seu desempenho na redação. Quando se fala em letramento e gêneros do discurso, assume-se a prática social da língua como inerente ao processo de interação. Outro item que vai de encontro à afirmação do INEP, refere-se aos gêneros que os participantes declaram maior frequência leitora.

Sabe-se que a apropriação e boa elaboração da escrita não se dão apenas pela leitura, mas pela prática de produção textual que tem sua base na escola. Isso implica afirmar que a leitura, nesse caso, forneceria subsídios para que o participante pudesse discorrer com fluência sobre sua proposta de intervenção. Todavia, não é apenas o bom repertório que garantirá o bom desempenho, mas a aplicação coerente e organizada das ideias, a fim de convencer o leitor (objetivo central nas teses). E tal elaboração exige prática, razão pela qual o letramento é fundamental.

Portanto, realizando o cruzamento dos dados das tabelas 1 (Distribuição dos "hábitos de leitura" e 2 (Desempenho Geral e Desempenho na Competência 5), e dos quadros 1 a 3 (Temas e textos-motivadores) observa-se que, em 2004, com o pior desempenho geral do período, que foi de $48,95 \%$, os textos oferecidos como motivadores foram: trechos de livro sobre comunicação e extratos de sites (ambos sobre ética), um artigo de lei e uma charge, mais relacionados às esferas que os participantes declararam pouca leitura, logo, pouco conhecimento. Reafirma-se, nesse sentido, que o bom desempenho na escrita não está estritamente vinculado à prática de leitura, já que, como afirma Serafini (1995):

só quando se escreve frequentemente é possível aprender a compor, embora a capacidade de escrever não melhore de modo significativo sem que as instruções e os conselhos sejam adequados. É preciso escrever não só nas aulas de português, mas também nas outras disciplinas. Cada matéria requer um léxico particular e uma estruturação diferente do texto; imagine-se como diferem textos de matemática dos de ciências. (SERAFINI, 1995, p. 54).

Conforme a autora, o processo de escrita reflete a seleção e organização de informações pelo escritor. Consequentemente, conclui-se que o escritor precisa - não só - de um repertório de leituras para ter o que dizer em seu texto, mas que, pela prática social que deve iniciar na escola, ele aproprie-se de como dizer. Seguindo esse raciocínio, nota-se que dentre os temas escolhidos, o que gerou pior desempenho na competência 5 foi "Como garantir a liberdade de informação e evitar abusos nos meios de comunicação?", resultando em 42,93\%. Em contrapartida, o que melhor resultado gerou foi: "Direitos da criança e do adolescente: como enfrentar esse desafio nacional?", com 57,51\% no desempenho da aptidão requerida. Pode-se inferir, por meio desses resultados, que os participantes teriam muito mais subsídios de leitura, conhecimento e informações (base A, fig. 1) sobre os direitos da criança (assunto abordado na escola desde os primeiros anos) do que sobre ética na TV (título de um dos textos-motivadores). 
Baseando-se nessa relação (tema $\mathrm{x}$ conhecimento $\mathrm{x}$ desempenho), o segundo melhor desempenho no período foi o de 2008, no qual os participantes receberam um trecho (adaptado) de reportagem jornalística como único texto-motivador, devendo elaborar proposta de intervenção para uma de três hipóteses apresentadas, o que resultou num desempenho geral de 59,35\%. Foi, ainda, a única edição na qual os participantes receberam três sugestões detalhadas - como proposta de intervenção (BRASIL, 2008a). Desse modo, a reportagem, mais próxima das práticas de leitura relatadas pelos participantes nos questionários socioeconômicos, aliada às pormenorizadas sugestões de propostas de intervenção, podem ter contribuído, ainda que minimamente, para a elevação do desempenho nessa edição.

\section{CONSIDERAÇÕES FINAIS}

Reverberando as palavras de Bakhtin (2011 [1979]), os resultados dos desempenhos dos participantes podem revelar que:

quanto melhor dominamos os gêneros tanto mais livremente os empregamos, tanto mais plena e nitidamente descobrimos neles a nossa individualidade (onde isso é possível e necessário), refletimos de modo mais flexível e sutil a situação singular da comunicação; em suma, realizamos de modo mais acabado o nosso livre projeto de discurso. (BAKHTIN, 2011 [1979], p. 285).

Tal assertiva sinaliza para a influência do letramento na redação e na vida dos participantes. Dessa maneira, o ensino de língua fundamentado nas práticas sociais de leitura e escrita, tendo como centro os gêneros do discurso que envolvem interação, contexto e dialogia, atuará como facilitador, já que os letramentos objetivam as práticas sociais e estas têm nos gêneros do discurso seu objeto de ensino.

Os dados analisados nessa pesquisa reforçam a relevância da participação da escola no letramento do aluno, sobretudo na forma como essa principal agência de letramento conduz o letramento ideológico. É preciso atentar para os letramentos locais, globais e multiletramentos, como propõe Rojo (2009), não apenas para garantir o alcance do topo da pirâmide do ENEM (fig. 1), mas para efetivar o protagonismo do aluno no cenário social.

$\mathrm{E}$, lançando o olhar para os recortes aqui citados aos documentos que parametrizam o ensino e a aprendizagem de língua nas escolas, suas afinidades com as teorias dos gêneros do discurso, logo, com os conceitos de dialogia, contexto e interação defendidos por Bakhtin, depreende-se que o problema de desempenho dos participantes não está no currículo prescrito ou, conforme Sacristán (2000), oficial, mas em sua aplicação ou aproveitamento, isto é, no que o autor chama de currículo oculto. Para ele,

os currículos escolares continuam sendo a fonte da validação acadêmica e profissional numa sociedade em que a sanção administrativa da cultura adquirida através do currículo, tem consequências tão importantes no mercado de trabalho e nas relações sociais. O currículo escolar, frente a toda essa concorrência exterior, talvez esteja perdendo o monopólio da transmissão de certos valores culturais explícitos, mas reforça, por isso 
mesmo, outras funções do currículo oculto da instituição escolar: socialização, inculcação de pautas de comportamento, valores sociais, validação para subir pela pirâmide social, etc. (SACRISTÁN, 2000, p. 74).

Importa observar que o conceito de letramento tem na escola sua principal, mas não exclusiva, agência de letramento. Há outras agências como a família e associações, por exemplo, que também interferem no letramento. Sem a intenção, porém, de apontar responsáveis, fica evidente a importância do letramento na e para a vida do educando. Têmse dois conceitos que, circulando em sintonia nas escolas (letramentos e gêneros do discurso), oferecem ao participante da esfera escolar a possibilidade de ampliar sua participação social e, consequentemente, seu protagonismo nas relações com a sociedade. Sem a pretensão de ser a última voz neste estudo, vislumbra-se a inclusão da dialogia e do letramento como alicerces da didática escolar, mas que contemplem, sobretudo, as produções textuais (redações) requeridas pelo ENEM. De qualquer forma, mesmo garantidas as condições dialógicas de produção cabe ainda à escola e ao aluno investir nas bases de seu letramento, que incluem tanto as práticas sociais de leitura como as de escrita. Nesse sentido, sem a prática social da escrita (ainda que haja práticas de leitura), os alunos não alcançarão o topo da pirâmide do ENEM (fig. 1), ou seja, o desempenho esperado, o protagonismo defendido por Freire. O fluxo é constante e contínuo: investir em práticas de leitura, mas também efetuar práticas de escrita. Esse é o caminho ininterruptamente social do ensino de língua, bem como do sucesso na redação do ENEM.

\section{REFERÊNCIAS}

BAKHTIN, M. M. [VOLOCHINOV, V. N.]. Marxismo e filosofia da linguagem: problemas fundamentais do método sociológico na ciência da linguagem. 13.ed. São Paulo: Hucitec, 2012 [1929].

BAKHTIN, M.M. Estética da criação verbal. 6.ed. São Paulo: Editora WMF Martins Fontes, 2011 [1979]. [1920/1924].

Para uma filosofia do ato responsável. São Carlos: Pedro \& João Editores, 2012

BARTON; HAMILTON, M.; IVANIČ, R. Situated literacies: reading and writing in context. London: Routledge, 2000.

BRASIL. A redação no ENEM 2013: guia do participante. Secretaria de Educação Básica. Brasília: Ministério da Educação, 2013. Disponível em:

$<$ http://ensinomediodigital.fgv.br/staticpages/guia_participante_redacao_enem_2013.pdf >. Acesso em: 2 out. 2013.

ENEM: relatório pedagógico 2008. Secretaria de Educação Básica. Brasília: Ministério da Educação, 2009. Disponível em: <http://portal.inep.gov.br/web/enem/edicoesanteriores/relatorios-pedagogicos>. Acesso em: 2 out. 2013.

Caderno de Prova Amarelo. Secretaria de Educação Básica. Brasília: Ministério da Educação, 2008. Disponível em: <http://inep.gov.br/web/enem/edicoes-anteriores/provas-egabaritos>. Acesso em: 4 out. 2013. (2008a). 
ENEM: relatório pedagógico 2006. Secretaria de Educação Básica. Brasília: Ministério da Educação, 2008. Disponível em: <http://portal.inep.gov.br/web/enem/edicoesanteriores/relatorios-pedagogicos>. Acesso em: 2 out. 2013. (2008b).

2007. Secretaria de Educação Básica. Brasília: Ministério da Educação, 2008. Disponível em: <http://portal.inep.gov.br/web/enem/edicoes-anteriores/relatoriospedagogicos >. Acesso em: 2 out. 2013. (2008c).

Caderno de Prova Amarelo. Secretaria de Educação Básica. Brasília: Ministério da Educação, 2007. Disponível em: <http://inep.gov.br/web/enem/edicoes-anteriores/provas-egabaritos>. Acesso em: 4 out. 2013. (2007a).

ENEM: relatório pedagógico 2003. Secretaria de Educação Básica. Brasília:

Ministério da Educação, 2007. Disponível em: <http://portal.inep.gov.br/web/enem/edicoesanteriores/relatorios-pedagogicos>. Acesso em: 2 out. 2013. (2007b).

2004. Secretaria de Educação Básica. Brasília: Ministério da Educação,

2007. Disponível em: <http://portal.inep.gov.br/web/enem/edicoes-anteriores/relatoriospedagogicos>. Acesso em: 2 out. 2013. (2007c).

2005. Secretaria de Educação Básica. Brasília: Ministério da Educação, 2007. Disponível em: <http://portal.inep.gov.br/web/enem/edicoes-anteriores/relatoriospedagogicos>. Acesso em: 2 out. 2013. (2007d).

PCN+ Ensino Médio: orientações educacionais complementares aos Parâmetros Curriculares Nacionais. Linguagens, códigos e suas tecnologias. Secretaria de Educação Básica. Brasília: Ministério da Educação, 2007. Disponível em:

$<$ http://portal.mec.gov.br/index.php?option=com_content\&view=article\&id=12598:publicaco es>. Acesso em: 2 out. 2014. (2007e).

. Caderno de Prova Amarelo. Secretaria de Educação Básica. Brasília: Ministério da Educação, 2006. Disponível em: <http://inep.gov.br/web/enem/edicoes-anteriores/provas-egabaritos>. Acesso em: 4 out. 2013.

. Secretaria de Educação Básica. Brasília: Ministério da Educação, 2005.

Disponível em: <http://inep.gov.br/web/enem/edicoes-anteriores/provas-e-gabaritos>. Acesso em: 4 out. 2013.

Secretaria de Educação Básica. Brasília: Ministério da Educação, 2004.

Disponível em: <http://inep.gov.br/web/enem/edicoes-anteriores/provas-e-gabaritos>. Acesso em: 4 out. 2013. (2004a).

Relatório Final Enem 2003. Secretaria de Educação Básica. Brasília: Ministério da Educação, 2004. (2004b).

Caderno de Prova Amarelo. Secretaria de Educação Básica. Brasília: Ministério da Educação, 2003. Disponível em: <http://inep.gov.br/web/enem/edicoes-anteriores/provas-egabaritos>. Acesso em: 4 out. 2013.

Secretaria de Educação Básica. Brasília: Ministério da Educação, 2002.

Disponível em: <http://inep.gov.br/web/enem/edicoes-anteriores/provas-e-gabaritos >. Acesso em: 4 out. 2013. (2002a).

. ENEM: relatório pedagógico 2002. Secretaria de Educação Básica. Brasília:

Ministério da Educação, 2002. Disponível em: <http://portal.inep.gov.br/web/enem/edicoesanteriores/relatorios-pedagogicos>. Acesso em: 2 out. 2013. (2002b). 
Caderno de Prova Amarelo. Secretaria de Educação Básica. Brasília: Ministério da Educação, 2001. Disponível em: <http://inep.gov.br/web/enem/edicoes-anteriores/provas-egabaritos>. Acesso em: 4 out. 2013. (2001a).

ENEM: relatório pedagógico 2000. Secretaria de Educação Básica. Brasília:

Ministério da Educação, 2001. Disponível em:

<http://www.publicacoes.inep.gov.br/resultados.asp>. Acesso em: 2 out. 2013. (2001b).

2001. Secretaria de Educação Básica. Brasília: Ministério da Educação,

2001. Disponível em: <http://portal.inep.gov.br/web/enem/edicoes-anteriores/relatoriospedagogicos>. Acesso em: 2 out. 2013. (2001c).

Caderno de Prova Amarelo. Secretaria de Educação Básica. Brasília: Ministério da Educação, 2000. Disponível em: <http://inep.gov.br/web/enem/edicoes-anteriores/provas-egabaritos>. Acesso em: 4 out. 2013. (2000a).

. Parâmetros Curriculares Nacionais (Ensino Médio). Parte II: Linguagens, códigos e suas tecnologias. Secretaria de Educação Básica. Brasília: Ministério da Educação, 2000.

Disponível em:

$<$ http://portal.mec.gov.br/index.php?id=12598:publicacoes\&option=com_content\&view=artic le>. Acesso em: 11 out. 2013. (2000b).

Parâmetros curriculares nacionais: terceiro e quarto ciclos do ensino fundamental: língua portuguesa. Brasília: Ministério da Educação, 1998.

Lei Darcy Ribeiro: Lei 9.394/96 - Lei de Diretrizes e Bases da Educação Nacional. Brasília, 1997.

BRITTO, L. P. L. Inquietudes e desacordos: a leitura além do óbvio. Campinas, SP: Mercado de Letras, 2012.

CELANI, M. A. A. Questões de ética na pesquisa em Linguística Aplicada. In: Linguagem \& Ensino, Pelotas (RS), v. 8, n. 1, p. 101-122, jan./jun. 2005. Disponível em:

<http://rle.ucpel.edu.br/index.php/rle/article/viewFile/198/165>. Acesso em: 10 out. 2013.

ENEM: faculdades federais e particulares. Disponível em:

$<$ http://enem.net/enem-faculdades-federais-e-particulares.html>. Acesso em 11 out. 2013.

FREIRE, P. A importância do ato de ler: em três artigos que se completam. 51. ed. São Paulo: Cortez, 2011.

GEE, J. P. Language and literacy: reading Paulo Freire empirically. 2009. Disponível em: <http://www.jamespaulgee.com/node/25>. Acesso em: 12 fev. 2014.

Social Linguistics and Literacies: ideology in discourses. 3. ed. Palmer Press:

London, 2008 [1990].

GERALDI, J. W. Portos de passagem. 5. ed. São Paulo: Editora WMF Martins Fontes, 2013 [1991].

GNERRE, M. Linguagem, escrita e poder. 5. ed. São Paulo: Editora WMF Martins Fontes, 2009.

GRAMSCI, A. Os intelectuais e a organização da cultura. 4. ed. Rio de Janeiro: Editora Civilização Brasileira, 1982.

HEATH, S. B. What no bedtime story means: narrative skills at home and school. In:

Language in society. v. 11, n. 1, p. 49-76. Cambridge: Cambridge University Press, 1982. 
KATO, M. A. No mundo da escrita: uma perspectiva psicolingüística. São Paulo: Ática, 1986.

KLEIMAN, A. B. Letramento e suas implicações para o ensino de língua materna. Signo. Santa Cruz do Sul, v. 32 n. 53, p. 1-25, dez, 2007. Disponível em: $<$ https://online.unisc.br/seer/index.php/signo/article/download/242/196>. Acesso em: 10 out. 2013.

Abordagens da leitura. SCRIPTA, Belo Horizonte, v. 7, n. 14, p. 13-22, $1^{\circ}$ sem. 2004. Disponível em:

$<$ http://ich.pucminas.br/cespuc/Revistas_Scripta/Scripta14/Conteudo/N14_Parte01_art01.pdf >. Acesso em: 11 mar. 2014.

Texto e Leitor: aspectos cognitivos da leitura. 8. ed. Campinas: Pontes, 2002. Os significados do letramento. Campinas, Mercado de Letras, 1995.

KOCH, I. G. V. A possibilidade de intercâmbio entre Linguística Textual e o ensino de língua materna. In: Veredas, revista de estudos linguísticos. Juiz de Fora, v. 5, n. 2, p. 85-94. 2009. Disponível em: <http://www.ufjf.br/revistaveredas/files/2009/12/cap073.pdf>. Acesso em: 13 mar. 2014.

PONTUAL, H. D. ENEM. Agência Senado. Disponível em: <http://www12.senado.gov.br/noticias/entenda-o-assunto/enem>. Acesso em: 11 out. 2013. RODRIGUES, R. H. [et al.]. Linguística textual: $4^{\circ}$ período. Florianópolis: UFSC/LLV/CCE, 2012.

RODRIGUES, R. H. Os gêneros do discurso na perspectiva dialógica da linguagem: a abordagem de Bakhtin. In: MEURER, J.L.; BONINI, A.; MOTA-ROTH, D. (Orgs.) Gêneros: teorias, métodos e debates. São Paulo: Parábola Editorial, 2005, p.152-183.

ROJO, R. Letramentos múltiplos, escola e inclusão social. São Paulo: Parábola Editorial, 2009.

SACRISTÁN, J. G. O currículo: uma reflexão sobre a prática. 3. ed. Porto Alegre: Artmed, 2000 .

SERAFINI, M. T. Como escrever textos. 7. ed. São Paulo: Globo, 1995.

SERRA, E. D. Políticas de promoção da leitura. In: RIBEIRO, V. M. (org.) Letramento no Brasil: reflexões a partir do INAF 2001. São Paulo: Global, 2003, p.65-85.

SILVEIRA, A. P. K.; ROHLING, N; RODRIGUES, R. H. A análise dialógica dos gêneros do discurso e os estudos do letramento: glossário para leitores iniciantes. Florianópolis:

DIOESC, 2012.

SOARES, M. Letramento: um tema em três gêneros. Belo Horizonte: Autêntica, 1998.

STREET, B. V. Perspectivas interculturais sobre o letramento. Revista Filologia. n. 8, p.465488, 2007. Disponível em: <http://dlcv.fflch.usp.br/sites/dlcv.fflch.usp.br/files/Street.pdf>. Acesso em: 13 out. 2013.

What's "new" in New Literacy Studies? Critical approaches to literacy in theory and practice. Current Issues in Comparative Education, Teachers College, Columbia University, Vol. 5(2), 2003. 
Cross-cultural Approaches to Literacy. Cambridge: Cambridge University Press, 1993.

Literacy in theory and practice. Cambridge: Cambridge University Press, 1984.

TFOUNI, L.V. Adultos não alfabetizados: o avesso do avesso. Campinas: Pontes, 1988.

TRAVAGLIA, L. C. Aspectos da pesquisa sobre tipologia textual. Revista de estudos da linguagem. Belo Horizonte: Faculdade de Letras da UFMG, v. 20, n. 2, p. 361-387, jul./dez. 2012. Disponível em:

$<$ http://www.ileel.ufu.br/travaglia/artigos/artigo_aspectos_da_pesquisa_sobre_tipologia_textu al.pdf>. Acesso em: 14 fev. 2014.

Recebido em: 01/03/2014

Aceito em: 29/03/2014 